\title{
Cytokine Storm Syndrome Associated with Hemorrhagic Fever and Other Viruses
}

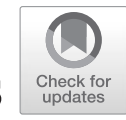

\author{
Ethan S. Sen and A. V. Ramanan
}

\section{Introduction}

Cytokine storm syndrome (CSS) results from the failure to regulate appropriately the immune response with particular dysfunction of cytotoxic T cells and NK cells [1]. A potent trigger for activation of these cells is infection, and particularly viral infections, in subjects both with and without genetic mutations associated with primary HLH (pHLH) [2]. The most common viral infection triggering CSS is Epstein-Barr virus (EBV) and was the cause in $74 \%$ of children in whom an infectious agent was identified from a cohort of 219 with infection-associated CSS [3]. CSS associated with EBV and other herpes viruses are discussed elsewhere and the focus of this chapter will be other viruses, including hemorrhagic fever viruses [4]. In order to diagnose virus-associated HLH, presence of the pathogen should be confirmed by serology (paired acute and convalescent samples) or specific viral polymerase chain reaction (PCR) testing of blood or tissue. Other infectious or noninfectious causes of secondary HLH would also need to be excluded, although in cases of severe or lifethreatening CSS prompt initiation of immunosuppressive / immunomodulatory treatment without delay is more important than determination of the underlying etiology.

\section{Viral Hemorrhagic Fevers}

The viral hemorrhagic fevers (VHFs) are caused by viruses belonging to one of five families: Arenaviridae, Bunyaviridae, Filoviridae, Falviviridae, and Togaviridae [5, 6]. They are all RNA viruses and require a nonhuman vertebrate or insect host to

\footnotetext{
E. S. Sen $\cdot$ A. V. Ramanan $(\bowtie)$

Pediatric Rheumatology, Bristol Royal Hospital for Children, Bristol, UK

e-mail: ethan.sen@doctors.org.uk
} 
provide a natural reservoir. Initial infection occurs when humans come into contact with a host but subsequently human-to-human transmission of some of these viruses does occur. Typical presenting features include fever, dizziness, fatigue, muscle aches and weakness. Frequently VHFs occur as outbreaks or epidemics. The viruses and infections they cause are summarized in Table 1.

A systematic review of sHLH in zoonoses conducted in 2012 and covering studies published between 1950 and 2012 identified reports of HLH associated with CrimeanCongo hemorrhagic fever (CCHF) and hantaviruses [7]. Multiple cases of sHLH linked to dengue [8-39], Chikungunya [40], CCHF [41-43], hantavirus [44], and severe fever with thrombocytopenia syndrome (Bunyavirus) [45-47] have been described.

Dengue is a relatively common tropical infection [48] and may progress to more severe forms: dengue hemorrhagic fever (DHF) and dengue shock syndrome (DSS). DHF is defined as dengue infection accompanied by fever lasting 2-7 days, hemorrhagic tendencies, thrombocytopenia and evidence of plasma leakage due to increased vascular permeability [49]. DSS is classified as DHF plus evidence of circulatory failure. The primary aspects of management are supportive with fluids and blood

Table 1 Viral hemorrhagic fever viruses and their associated diseases

\begin{tabular}{|c|c|c|c|}
\hline Virus family & Host & Examples & Disease \\
\hline \multirow[t]{3}{*}{ Arenaviridae } & \multirow{3}{*}{$\begin{array}{l}\text { Rodents-Spread } \\
\text { through contact with } \\
\text { excrement }\end{array}$} & Junin virus & $\begin{array}{l}\text { Argentine hemorrhagic } \\
\text { fever }\end{array}$ \\
\hline & & Lassa virus & Lassa fever \\
\hline & & Lujo virus & Lujo hemorrhagic fever \\
\hline \multirow[t]{3}{*}{ Bunyaviridae } & $\begin{array}{l}\text { Arthropods (ticks, } \\
\text { mosquitoes, sand flies) } \\
\text { and rodents }\end{array}$ & $\begin{array}{l}\text { Phlebovirus-Rift valley } \\
\text { fever virus }\end{array}$ & Rift valley fever \\
\hline & Ticks & $\begin{array}{l}\text { Nairovirus-Crimean- } \\
\text { Congo hemorrhagic fever } \\
\text { virus }\end{array}$ & $\begin{array}{l}\text { Crimean-Congo } \\
\text { hemorrhagic fever }\end{array}$ \\
\hline & Rodents & $\begin{array}{l}\text { Hantavirus-Hantaan } \\
\text { virus } \\
\text { Sin Nombre virus }\end{array}$ & $\begin{array}{l}\text { Hemorrhagic fever with } \\
\text { renal syndrome (HFRS) } \\
\text { Hantavirus pulmonary } \\
\text { syndrome (HPS) }\end{array}$ \\
\hline \multirow[t]{2}{*}{ Filoviridae } & Fruit bats, Rousettus bats & Marburgvirus & $\begin{array}{l}\text { Marburg hemorrhagic } \\
\text { fever }\end{array}$ \\
\hline & Fruit bats, primates & Ebolavirus & Ebola hemorrhagic fever \\
\hline \multirow[t]{6}{*}{ Flaviviridae } & Mosquitoes & Yellow fever virus & Yellow fever \\
\hline & Mosquitoes & Dengue virus & $\begin{array}{l}\text { Dengue fever, dengue } \\
\text { hemorrhagic fever }\end{array}$ \\
\hline & Mosquitoes & Japanese encephalitis virus & Japanese encephalitis \\
\hline & Mosquitoes & West Nile virus & West Nile fever \\
\hline & Mosquitoes & Zika virus & Zika \\
\hline & Ticks & $\begin{array}{l}\text { Tick-borne encephalitis } \\
\text { virus }\end{array}$ & Tick-borne encephalitis \\
\hline Togaviridae & & Chikungunya virus & Chikungunya \\
\hline
\end{tabular}

Adapted from $[5,6]$ 
products as required [50]. Corticosteroids have been used; however, there has been uncertainty among clinicians about the efficacy and safety of corticosteroids in treatment of dengue with some considering them harmful [51]. An RCT of oral prednisolone $(0.5 \mathrm{mg} / \mathrm{kg}$ or $2 \mathrm{mg} / \mathrm{kg}$ daily for 3 days) versus placebo, which included 225 patients with early dengue infection, found no prolongation of viremia or other adverse events in the steroid recipients [52]. It was not powered to assess efficacy; however, there appeared to be no reduction in the development of shock or other dengue-related complications. A Cochrane review published in 2014 which included 8 RCTs or quasi-randomized studies found the evidence to be of low or very low quality and insufficient to conclude whether corticosteroids are of benefit in dengue at an early stage or DSS [53]. Others, however, have suggested that the timing of steroids and patient selection may be critical [54]. A non-randomized retrospective study of adults with DSS with the most severe disease found those given a single dose of methylprednisolone ( $1 \mathrm{~g}$ intravenously) as a rescue treatment had a lower mortality (13\%, 3/13 patients) than those not receiving steroids (47\%, 15/32 patients) [55]. In these most severely affected cases it may be that patients had developed CSS.

Dengue has frequently been the trigger for HLH [56]. A large study in India of 212 patients with dengue identified 31 (14.6\%) who developed CSS, including 23 with evidence of bone marrow hemophagocytosis [29]. In this group of 23 patients, 19 received IVIg and all recovered. Another study from Kolkata, India, reported 8 patients (2.2\%) with HLH of 358 with dengue during the outbreak in 2012 [27]. The 8 cases received supportive therapy, blood component transfusions as required and parenteral dexamethasone $\left(10 \mathrm{mg} / \mathrm{m}^{2}\right.$ in 3-4 divided doses/day) until hemodynamically stable before switching to oral tapering treatment for 21 days. IVIg $(1 \mathrm{~g} / \mathrm{kg})$ was used in one patient as rescue therapy after failing to respond to $48 \mathrm{~h}$ of steroids. The patients with HLH were distinguished by persistence of fever for more than 7 days together with prolonged or progressive cytopenias, organomegaly, and sterile cultures. In a series of 33 children with HLH from Chennai, India, an infectious etiology was identified in 14 and specifically dengue in 5 [57].

Using a case-control design comparing patients with dengue who developed HLH (cases, $n=22$ ) with patients with dengue without HLH (controls, $n=88$ ), one study found cases had a younger age (median 1 vs. 13 years, $p<0.01$ ), more frequent coinfection ( $18.2 \%$ vs. $4.5 \%, p=0.04)$, and longer duration of fever ( 7 vs. 5 days, $p<0.01$ ) [15]. Several studies have suggested testing for laboratory markers of HLH in cases of dengue, in particular ferritin, sCD163, and sCD25 $[9,10]$. In a cohort of 208 patients with dengue, ferritin and SCD163 were significantly increased in patients with severe dengue. A report including patients with dengue during an outbreak on Aruba in the Caribbean found that levels of ferritin were significantly higher in patients with dengue compared with other febrile illnesses [58]. In another cohort of dengue-infected patients in Brazil, hyperferritinemia was associated with disease severity and a pro-inflammatory cytokine profile [58].

The features of severe dengue infection, as seen in dengue hemorrhagic fever or dengue shock syndrome, overlap with HLH suggesting a similar pathogenesis involving overactivation of the immune system leading to a hypercytokinemia [58, 59]. These features also seem to be shared in some cases of CCHF [41, 43]. One 
reported a 14-year-old boy from Turkey with CCHF associated with leukopenia, thrombocytopenia, hypertriglyceridemia, hyperferritinemia and bone marrow hemophagocytosis. The pathogenesis of viral hemorrhagic fevers may overlap with CSS. A report of 5 patients with CCHF treated with high dose intravenous methylprednisolone (IVMP) suggested resolution of fever, increase in leukocyte and platelet counts and clinical improvement within 5 days of treatment [60]. Another study reported outcomes in 12 patients with CCHF treated with IVMP (up to $30 \mathrm{mg} / \mathrm{kg}$ / day), fresh frozen plasma (FFP), and intravenous immunoglobulin (IVIg) [61]. The treatment appeared to be successful with reduction of fever within 2 days, white cell count above $4500 / \mu \mathrm{L}$ in 4 days and platelets above $150,000 / \mu \mathrm{L}$ in 9 days. Finally, it has been suggested that Ebola outbreaks share many features of CSS [62-64].

While the VHFs represent an important group of viruses associated with CSS, a host of other viruses more commonly seen in North America and Europe can also trigger hemophagocytic syndromes.

\section{Nonhemorrhagic Fever Viruses}

A wide range of viruses other than those discussed above have been associated with CSS. These are summarized in Table 2 and reviewed in more detail below.

\section{Influenza and Parainfluenza}

CSS has been identified in association with seasonal influenza [65, 86-89], influenza A (H5N1, "avian flu") [90, 91], and pandemic influenza A (H1N1, 2009 "swine flu") infection [92-100]. In some cases, patients were immunocompromised or had additional risk factors such as leukemia $[86,97,98]$, post-bone marrow transplantation for lymphoma [93], genetic predisposition [101], or cystic fibrosis [99]. However, CSS developed in previously healthy individuals following influenza $\mathrm{H} 1 \mathrm{~N} 1$ and H5N1 leading to death in both adults [95] and children [91, 100, 102]. A case of HLH following influenza vaccination in a patient with aplastic anemia undergoing allogeneic bone marrow transplantation has also been documented [103].

During the 2009 influenza H1N1 pandemic, a center in Germany conducted a prospective observational study of 25 critically ill patients with the infection [66]. All developed severe acute respiratory distress syndrome and hypoxemia and were mechanically ventilated. HLH was diagnosed based on the presence of three of four major criteria (fever, cytopenia, hepatitis, or splenomegaly) and at least one minor criterion (evidence of hemophagocytosis in bone marrow samples or increase in serum level of sIL-2R $\alpha$ or ferritin, respectively). Nine (36\%) of 25 patients met these criteria and eight $(89 \%)$ of them died, compared with $4(25 \%)$ of 16 patients without HLH. Six of the patients with HLH were treated (four with etoposide and dexamethasone, two with steroids alone) but the other three were moribund at the 
Table 2 Nonhemorrhagic fever viruses associated with cytokine storm syndromes

\begin{tabular}{|c|c|c|c|}
\hline Virus & Clinical associations & Outcomes & References \\
\hline Influenza & $\begin{array}{l}\text { Pneumonia, myocarditis, } \\
\text { encephalitis, myositis }\end{array}$ & Mechanical ventilation, recovery & {$[65-67]$} \\
\hline Parainfluenza & $\begin{array}{l}\text { Croup, bronchiolitis, } \\
\text { pneumonia }\end{array}$ & Recovery & [68] \\
\hline Adenovirus & $\begin{array}{l}\text { Upper respiratory tract } \\
\text { infection, pneumonia, } \\
\text { conjunctivitis, gastroenteritis, } \\
\text { hepatitis, myocarditis, } \\
\text { encephalitis }\end{array}$ & $\begin{array}{l}\text { Recovery, more severe } \\
\text { manifestations in } \\
\text { immunocompromised hosts }\end{array}$ & {$[69,70]$} \\
\hline Parvovirus & $\begin{array}{l}\text { "Slapped cheek syndrome"/ } \\
\text { fifth disease, aplastic crisis, } \\
\text { arthropathy, hepatitis, } \\
\text { myocarditis }\end{array}$ & $\begin{array}{l}\text { Recovery, pure red cell aplasia, } \\
\text { chronic arthritis, hydrops fetalis, } \\
\text { chronic fatigue syndrome }\end{array}$ & [71] \\
\hline Hepatitis viruses & $\begin{array}{l}\text { Hepatitis, arthritis, } \\
\text { leukocytoclastic vasculitis }\end{array}$ & $\begin{array}{l}\text { Recovery (hepatitis A), chronic } \\
\text { hepatitis, cirrhosis, } \\
\text { hepatocellular carcinoma }\end{array}$ & {$[72-74]$} \\
\hline Measles & $\begin{array}{l}\text { Interstitial pneumonia, } \\
\text { encephalitis, } \\
\text { thrombocytopenic purpura }\end{array}$ & $\begin{array}{l}\text { Recovery, subacute sclerosing } \\
\text { panencephalitis }\end{array}$ & {$[75-77]$} \\
\hline Mumps & $\begin{array}{l}\text { Parotitis, pancreatitis, } \\
\text { orchitis, meningitis, } \\
\text { encephalitis }\end{array}$ & $\begin{array}{l}\text { Recovery, deafness, sterility } \\
\text { rarely after orchitis }\end{array}$ & {$[78,79]$} \\
\hline Rubella & $\begin{array}{l}\text { Arthralgia, arthritis, } \\
\text { encephalitis, congenital } \\
\text { rubella syndrome }\end{array}$ & $\begin{array}{l}\text { Deafness, developmental delay, } \\
\text { cardiovascular and ocular } \\
\text { defects in congenital rubella } \\
\text { syndrome }\end{array}$ & [80] \\
\hline Enterovirus & $\begin{array}{l}\text { Respiratory and } \\
\text { gastrointestinal infections, } \\
\text { pancreatitis, meningitis, } \\
\text { encephalitis, neonatal sepsis, }\end{array}$ & $\begin{array}{l}\text { Neurological impairment in } \\
\text { some children after meningitis }\end{array}$ & [81] \\
\hline Parechovirus & $\begin{array}{l}\text { Sepsis-like illness, } \\
\text { meningitis, encephalitis, } \\
\text { hepatitis }\end{array}$ & $\begin{array}{l}\text { Neurological sequelae in some } \\
\text { young infants }\end{array}$ & {$[82,83]$} \\
\hline Rotavirus & $\begin{array}{l}\text { Gastroenteritis, seizures, } \\
\text { encephalopathy/encephalitis }\end{array}$ & Recovery, rarely intussusception & [84] \\
\hline $\begin{array}{l}\text { Human } \\
\text { T-lymphotropic } \\
\text { virus }\end{array}$ & $\begin{array}{l}\text { Adult } \mathrm{T} \text { cell leukemia/ } \\
\text { lymphoma, demyelinating } \\
\text { disease, autoimmune diseases }\end{array}$ & $\begin{array}{l}\text { Tropical spastic paraparesis, } \\
\text { systemic lupus erythematosus, } \\
\text { Sjögren's syndrome }\end{array}$ & [85] \\
\hline
\end{tabular}

time of diagnosis with HLH and were not considered suitable for treatment. The study suggests that CSS/HLH may have been a significant contributor to multiorgan failure and death in critically ill patients during the influenza A H1N1 pandemic.

Reports have indicated that avian influenza A (H5N1) can lead to severe and widely disseminated infection outside the respiratory system. In one case, a previously healthy nine-year-old Vietnamese girl died following encephalitis and coma with virus detected in rectal swabs, serum and cerebrospinal fluid [102]. Hemophagocytosis was detected in bone marrow from several patients with H5N1 
infection [90, 91, 104-106]. In vitro studies indicated that recombinant hemagglutinin (H5) from H5N1 influenza suppressed perforin expression and reduced cytotoxicity of human $\mathrm{CD}^{+} \mathrm{T}$ cells to kill H5-bearing cells [107]. This failure of clearance of infected cells could promote lymphoproliferation and hypercytokinemia as seen in CSS. Another study measured cytokine levels in a familial group of patients with H5N1 influenza in Hong Kong and found particularly high serum concentrations of interferon induced protein-10 (also known as CXCL10) and monokine induced by interferon $\gamma$ (CXCL9) [108]. Taken together with other in vitro work, the authors suggest this hypercytokinemia may contribute to pathogenesis in fatal influenza infection. How might these cases be treated?

Drawing parallels with EBV-associated HLH, Henter et al. proposed a modified HLH-94 treatment protocol for influenza A (H5N1)-associated HLH in addition to antiviral and supportive therapy $[109,110]$. For children, they suggested intravenous etoposide $150 \mathrm{mg} / \mathrm{m}^{2}$ once per week and dexamethasone initially $10 \mathrm{mg} / \mathrm{m}^{2}$ once daily. They recommended reduced doses of both drugs in patients aged 15 years or older and advised against upfront use of cyclosporin A (CsA) in all cases due to the relative frequency of renal complications in H5N1 infection.

Influenza B has been suggested as the trigger for HLH in a 24-year-old man with systemic lupus erythematosus (SLE) [111]. Several weeks after his initial diagnosis of SLE when he presented with a pericardial effusion, he developed fever, erythematous rash, splenomegaly, hypertriglyceridemia, and ferritin of $95,703 \mathrm{ng} / \mathrm{mL}$. Influenza virus B was detected in the patient's nasal lavage sample and no other infective triggers for HLH were apparent. His pericardial effusion recurred with progression to cardiac tamponade, and he was managed with ventilation and pericardiocentesis. His condition initially improved after steroid pulse treatment, but he was started on colchicine $1 \mathrm{mg} /$ day after reaccumulation of the pericardial fluid. He remained stable on low-dose prednisolone and colchicine. The relative contributions of SLE and influenza infection to pathogenesis of CSS in this case are unclear. While many reports have associated influenza with HLH, parainfluenza has been documented once.

A case of CSS in a 33-year-old Chilean man characterized by fever, evanescent rash, hepatosplenomegaly, anemia, thrombocytopenia, hyperferritinemia, and hemophagocytosis on bone marrow biopsy was attributed to parainfluenza virus-2 infection detected by polymerase chain reaction (PCR) testing of respiratory and enteric samples [112]. He was treated with etoposide, dexamethasone, and CsA following the HLH-94 protocol, and he made a complete recovery remaining in remission after 2 years of follow-up.

\section{Adenovirus}

Adenovirus infections are frequent in childhood presenting with respiratory, gastrointestinal, or ocular manifestations [70]. These are usually mild in immunocompetent hosts but may lead to more severe disease including pneumonia, hepatitis, and encephalitis in the immunocompromised. 
CSS has been described in adults and children secondary to adenovirus infection [113-124]. It has occurred in previously healthy children with the initial presentation of pneumonia $[114,115,120]$. One of the patients was treated with dexamethasone and CsA and the other two with IVIg, and all recovered. In a large single-center study of HLH in children under 1 year of age, three of four infants with adenovirus-associated HLH survived [116]. A case in an adult while receiving chemotherapy for a solid tumor has been reported [121]. A young child being treated with chemotherapy for Langerhans cell histiocytosis developed recurrent viral-associated HLH, in one instance caused by adenovirus [117]. Several cases of adenovirus-associated HLH have been reported post-hematopoietic stem cell transplantation [113], associated with sJIA [119], and in brothers with X-linked agammaglobulinemia [124].

\section{Parvovirus}

Parvovirus B19 is the cause of erythema infectiosum (fifth disease or "slapped cheek syndrome"), which is common in childhood [71]. In addition to a rash, adults more frequently develop arthralgia and myalgia.

CSS has been reported in adults and children in association with parvovirus B19 infection [125-132]. One report detailed five previously healthy adults whose disease resolved spontaneously [133]. In other cases, the most frequent underlying disease was hereditary spherocytosis [4, 128]. Cases of CSS triggered by parvovirus B19 in patients with another underlying condition have been reported: post-renal transplant [134], post kidney-pancreas transplant [135], B-cell acute lymphoblastic leukemia [136], autoimmune hemolytic anemia [137], Evans syndrome (autoimmune hemolytic anemia and autoimmune thrombocytopenia) [138], and pregnancy [139].

Coinfection with parvovirus B19 and another pathogen has been reported in association with HLH in several cases, including EBV [126, 140] and Klebsiella [141].

Among 28 cases of parvovirus-associated HLH, the majority were woman over 15 years of age, and 22 survived despite 16 of them having no specific treatment [142]. This suggests a better prognosis than other forms of viral-associated CSS [4], although fatalities and serious complications such as acute myocarditis have been reported [143, 144]. Case reports have detailed use of glucocorticoids, IVIg, CsA, and anakinra (IL-1 receptor antagonist) in treatment of parvovirus B19-associated HLH [145].

In some of the cases of HLH attributed to parvovirus B19, viral nucleic acid was detected in blood or tissues by PCR. It is known that virus may persist for weeks or months, and therefore detection of viral DNA in tissues does not definitively confirm acute infection [71]. The most reliable marker of this is detection of virusspecific $\operatorname{IgM}$ and a fourfold increase or seroconversion of $\mathrm{IgG}$ in paired serum samples. However, care should be taken in interpretation of serology samples in patients after treatment with IVIg. 


\section{Hepatitis Viruses}

Various hepatitis viruses have been detected in association with CSS. Hepatitis A virus is the most-frequently reported [146-157]. Features of fulminant acute viral hepatitis may be similar to CSS. Hepatitis A-triggered MAS has been reported in several patients with underlying systemic JIA or Still disease [148, 154, 157]. Successful treatments for hepatitis A-triggered HLH have included glucocorticoids, IVIg [150, 156], and the HLH-2004 etoposide-based protocol [154]. In addition to hepatitis A, other hepatitis viruses have also been found to cause HLH.

Hepatitis B virus has been reported as a potential trigger for CSS [158, 159]. The first reported case did not respond to steroids, IVIg, or CsA, but the patient did respond to etoposide, although subsequently succumbed to fulminant infection [158]. A fatal case of CSS was reported in a patient with the combination of chronic active hepatitis $\mathrm{B}$ and acute hepatitis $\mathrm{C}$ infection despite intensive immunosuppressive (intravenous methylprednisolone, intravenous CsA, granulocyte-colony stimulating factor, IVIg, and anti-thymocyte globulin), and supportive treatment [160].

CSS was identified in a 60-year-old woman with chronic hepatitis $\mathrm{C}$ infection [161]. In this case, it was speculated whether the more acute triggers for development of sHLH were the interferon and ribavirin used as treatment for hepatitis $\mathrm{C}$ virus which were started 3 months before the characteristic features of CSS: fever, splenomegaly, coagulopathy, anemia, and thrombocytopenia.

Hepatitis E is typically a self-limited illness with average duration of 4-6 weeks and presenting with fever, nausea, vomiting, abdominal pain, anorexia, hepatomegaly, and jaundice [162]. CSS associated with hepatitis E infection has been reported in a small number of cases [163-165]. In one patient with rheumatoid arthritis, MAS developed within $24 \mathrm{~h}$ of her fourth tocilizumab infusion. Investigations for infections revealed positive serology, and hepatitis E virus RNA was detected in blood and stool by PCR [164]. In a second patient, sHLH appeared to be triggered by coinfection with hepatitis A and hepatitis E [165].

\section{Measles, Mumps, and Rubella Viruses}

CSS has occurred in a small number of cases following measles infection $[18,75$, $76,166]$. In eight of the cases patients developed interstitial pneumonia. The reported therapies included supportive treatment alone, intravenous methylprednisolone, or the HLH-2004 protocol. One case of sHLH following measles vaccination has been reported in a 19-month-old girl who developed persistent fever, hepatosplenomegaly, pancytopenia, liver dysfunction, and hemophagocytosis 1 week after vaccination [167]. A second case of suspected sHLH was reported in a previously healthy 14-month-old girl following the combined measles, mumps and rubella (MMR) vaccination and the authors speculate whether there may have been an underlying genetic predisposition [168]. 
Mumps infection has rarely been associated with CSS [78, 169]. In one case from China, a previously healthy 21-year-old male had persistent painful parotid gland swelling for 30 days and fever for 15 days together with typical features of CSS, including hemophagocytic macrophage infiltration on bone marrow biopsy. Anti-mumps virus IgM was positive but testing for bacteria and other viruses in peripheral blood was negative. Although there was initial response to high doses of methylprednisolone, IVIg, and etoposide, he succumbed 4 weeks after admission. In the second case, a 39-year-old female with parotitis and acute pancreatitis followed by features of CSS achieved complete response with corticosteroids.

Rubella virus-associated HLH has been reported in patients with ages ranging from young infants to adults [170-173]. In one case of a 26-year-old woman, serology was positive for both varicella-zoster virus (VZV) IgM and rubella virus IgM suggesting dual infection.

\section{Enterovirus}

Enteroviruses, which include the Coxsackieviruses and echoviruses, can cause a wide range of clinical presentations from mild respiratory and gastrointestinal infections, and hand-foot-and-mouth disease, to more severe conditions such as pancreatitis, meningitis, encephalitis, and neonatal sepsis [81]. Over 10 cases of enterovirus-associated CSS have been reported in the literature [116, 174-181]. One case occurred in an adult infected with Coxsackie virus A9 [174]. However, a significant proportion were in neonates or infants [116, 175, 179-181]. A case of vertical transmission of Coxsackie virus B1 leading to HLH in a 4-day-old neonate was reported with virus isolated in the throat and stool, and exclusion of inherited disease with normal perforin and CD107a expression [180]. The baby was successfully treated with corticosteroids, CsA, and etoposide. A case of fatal HLH was described in a 4-month-old infant with liver dysfunction (AST 626 IU/L, ALT 121 IU/L), high ferritin (1100 ng/mL), and hemophagocytosis in a liver biopsy [176].

\section{Parechovirus}

Virus of the Parechovirus genus are within the family Picornaviridae and were previously considered to be within the Enterovirus genus [81]. Human parechovirus-3 (HPeV-3) in neonates and infants can manifest with a sepsis-like presentation, and one publication has reported young infants with fever, rash, leukopenia, thrombocytopenia, and hyperferritinemia [181]. This and other studies have suggested that $\mathrm{HPeV}-3$ can cause an HLH-like illness, although the reason why other types of $\mathrm{HPeV}$ do not seem to cause a similar febrile illness is not clear [82]. 


\section{Rotavirus}

Rotavirus is one of the leading causes of infectious, dehydrating gastroenteritis in children globally with over 200,000 deaths reported annually [84]. CSS associated with rotavirus infection has been described in a small number of cases in the published literature [182-184]. In two of the cases there were significant underlying conditions. In the first, a 67-year-old man developed rotavirus enteritis 1 month after live-unrelated renal transplantation, and he developed fever, pancytopenia, altered consciousness, elevated liver enzymes, hypofibrinogenemia, and hyperferritinemia [182]. He also had herpes zoster infection and varicella zoster virus DNA was detected in his CSF. Bone marrow analysis confirmed hemophagocytosis, and he responded to acyclovir and pulsed methylprednisolone therapy. The second case was a 3-year-old child approximately 30 months after allogeneic hematopoietic stem cell transplantation for familial HLH [183]. She developed fever, diarrhea and lethargy, and she progressed to multiorgan failure meeting six of the HLH criteria on day 2 of admission. At this stage, rotavirus antigen was detected in stool and all other bacterial, viral, and fungal testing was negative. She received high dose corticosteroids and IVIg but developed invasive fungal infection and succumbed 4 weeks later.

\section{Human T-Lymphotropic Virus}

Human T-lymphotropic viruses (HTLVs) belong to the family of retroviruses. HTLV type-1 (HTLV-1) is associated with adult T cell leukemia/lymphoma, demyelinating disease, and autoimmune conditions [85]. A case has been reported of a woman who was a carrier of HTLV-1 who was diagnosed as having adult T-cell leukemia/lymphoma and B cell lymphoma-associated hemophagocytic syndrome [185]. HTLV type-3, the cause of AIDS, and its association with CSS is covered in a separate chapter in this textbook.

\section{Conclusion}

Viruses are the single most common infectious trigger for the final common pathway resulting in CSS. Identification of the pathogen usually requires serological or PCR testing, although caution is required in interpretation of these investigations in relation to the timing of the acute infection. In many of the reported cases, development of CSS appeared to be multifactorial involving more than a single infectious agent sometimes on a background of genetic predisposition, malignancy, immune suppression, or rheumatological disease. In the acute setting of life-threatening CSS, determining the etiology is subsidiary to management with multiorgan supportive therapy and high-dose glucocorticoids. Other than a modified HLH-94 
treatment protocol for influenza A (H5N1)-associated HLH, there is no evidence from controlled trials for a particular treatment regime based on the triggering virus.

Author Contributions E. S. Sen performed a literature review and wrote the chapter. A. V. Ramanan made contributions to reviewing and editing of the manuscript before submission. Competing Interests Statement

E. S. Sen declares no competing interests.

A. V. Ramanan has received speaker fees from SOBI.

\section{References}

1. Sen, E. S., Clarke, S. L., \& Ramanan, A. V. (2016). Macrophage activation syndrome. Indian Journal of Pediatrics, 83, 248-253.

2. Sen, E. S., Steward, C. G., \& Ramanan, A. V. (2017). Diagnosing haemophagocytic syndrome. Archives of Disease in Childhood, 102, 279-284.

3. Janka, G., Imashuku, S., Elinder, G., Schneider, M., \& Henter, J. I. (1998). Infection- and malignancy-associated hemophagocytic syndromes. Secondary hemophagocytic lymphohistiocytosis. Hematology/Oncology Clinics of North America, 12, 435-444.

4. Maakaroun, N. R., Moanna, A., Jacob, J. T., \& Albrecht, H. (2010). Viral infections associated with haemophagocytic syndrome. Reviews in Medical Virology, 20, 93-105.

5. World Health Organisation. (2017). Haemorrhagic fevers, viral. http://www.who.int/topics/ haemorrhagic_fevers_viral/en/.

6. Centers for Disease Control and Prevention. (2014). Viral hemorrhagic fevers (VHFs). https://www.cdc.gov/vhf/.

7. Cascio, A., Pernice, L. M., Barberi, G., Delfino, D., Biondo, C., Beninati, C., et al. (2012). Secondary hemophagocytic lymphohistiocytosis in zoonoses. A systematic review. European Review for Medical and Pharmacological Sciences, 16, 1324-1337.

8. Waxman, M. A. (2014). Update on emerging infections from the Centers for Disease Control and Prevention. Fatal hemophagocytic lymphohistiocytosis associated with locally acquired dengue virus infection-New Mexico and Texas, 2012. Annals of Emergency Medicine, 64, 55-57. discussion 58.

9. Ab-Rahman, H. A., Wong, P. F., Rahim, H., Abd-Jamil, J., Tan, K. K., Sulaiman, S., et al. (2015). Dengue death with evidence of hemophagocytic syndrome and dengue virus infection in the bone marrow. Springerplus, 4, 665.

10. Ab-Rahman, H. A., Rahim, H., AbuBakar, S., \& Wong, P. F. (2016). Macrophage activation syndrome-associated markers in severe dengue. International Journal of Medical Sciences, 13, 179-186.

11. Arshad, U., Ahmad, S. Q., \& Khan, F. (2015). Hemophagocytic lymphohistiocytosis in a patient with dengue infection. Hematology/Oncology and Stem Cell Therapy, 8, 189-190.

12. Chung, S. M., Song, J. Y., Kim, W., Choi, M. J., Jeon, J. H., Kang, S., et al. (2017). Dengueassociated hemophagocytic lymphohistiocytosis in an adult: A case report and literature review. Medicine, 96, e6159.

13. De Koninck, A. S., Dierick, J., Steyaert, S., \& Taelman, P. (2014). Hemophagocytic lymphohistiocytosis and dengue infection: Rare case report. Acta Clinica Belgica, 69, 210-213.

14. Ray, S., Kundu, S., Saha, M., \& Chakrabarti, P. (2011). Hemophagocytic syndrome in classic dengue fever. Journal of Global Infectious Diseases, 3, 399-401.

15. Ellis, E. M., Sharp, T. M., Perez-Padilla, J., Gonzalez, L., Poole-Smith, B. K., Lebo, E., et al. (2016). Incidence and risk factors for developing dengue-associated hemophagocytic lymphohistiocytosis in Puerto Rico, 2008-2013. PLoS Neglected Tropical Diseases, 10, e0004939. 
16. Jain, D., \& Singh, T. (2008). Dengue virus related hemophagocytosis: A rare case report. Hematology (Amsterdam, Netherlands), 13, 286-288.

17. Jasmine, Y. S., Lee, S. L., \& Kan, F. K. (2017). Infection associated haemophagocytic syndrome in severe dengue infection - a case series in a district hospital. The Medical Journal of Malaysia, 72, 62-64.

18. Joshi, R., Phatarpekar, A., Currimbhoy, Z., \& Desai, M. (2011). Haemophagocytic lymphohistiocytosis: A case series from Mumbai. Annals of Tropical Paediatrics, 31, 135-140.

19. Kapdi, M., \& Shah, I. (2012). Dengue and haemophagocytic lymphohistiocytosis. Scandinavian Journal of Infectious Diseases, 44, 708-709.

20. Kobayashi, K., Hikone, M., Sakamoto, N., Iwabuchi, S., Kashiura, M., Takasaki, T., et al. (2015). Dengue-associated hemophagocytic syndrome in a Japanese traveler: A case report. Journal of Travel Medicine, 22, 64-66.

21. Koshy, M., Mishra, A. K., Agrawal, B., Kurup, A. R., \& Hansdak, S. G. (2016). Dengue fever complicated by hemophagocytosis. Oxford Medical Case Reports, 2016, 121-124.

22. Krithika, M. V., Amboiram, P., Latha, S. M., Ninan, B., Suman, F. R., \& Scott, J. (2017). Neonate with haemophagocytic lymphohistiocytosis secondary to dengue infection: A case report. Tropical Doctor, 47, 253-255.

23. Lakhotia, M., Pahadiya, H. R., Gandhi, R., Prajapati, G. R., \& Choudhary, A. (2016). Stuck with pancytopenia in dengue fever: Evoke for hemophagocytic syndrome. Indian journal of critical care medicine : peer-reviewed, official publication of Indian Society of. Critical Care Medicine, 20, 55-56.

24. Lu, P. L., Hsiao, H. H., Tsai, J. J., Chen, T. C., Feng, M. C., Chen, T. P., et al. (2005). Dengue virus-associated hemophagocytic syndrome and dyserythropoiesis: A case report. The Kaohsiung Journal of Medical Sciences, 21, 34-39.

25. Mitra, S., \& Bhattacharyya, R. (2014). Hemophagocytic syndrome in severe dengue fever: A rare presentation. Indian Journal of Hematology \& Blood Transfusion, 30, 97-100.

26. My, L. T., Lien le, B., Hsieh, W. C., Imamura, T., Anh, T. N., Anh, P. N., et al. (2010). Comprehensive analyses and characterization of haemophagocytic lymphohistiocytosis in Vietnamese children. British Journal of Haematology, 148, 301-310.

27. Pal, P., Giri, P. P., \& Ramanan, A. V. (2014). Dengue associated hemophagocytic lymphohistiocytosis: A case series. Indian Pediatrics, 51, 496-497.

28. Pongtanakul, B., Narkbunnam, N., Veerakul, G., Sanpakit, K., Viprakasit, V., Tanphaichitr, V. T., et al. (2005). Dengue hemorrhagic fever in patients with thalassemia. Journal of the Medical Association of Thailand = Chotmaihet Thangphaet, 88(Suppl 8), S80-S85.

29. Raju, S., Kalyanaraman, S., Swaminathan, K., Nisha, A., \& Praisid, S. (2014). Hemophagocytic lymphohistiocytosis syndrome in dengue hemorrhagic fever. Indian Journal of Pediatrics, 81, 1381-1383.

30. Ramanathan, M., \& Duraisamy, G. (1991). Haemophagocytosis in dengue haemorrhagic fever: A case report. Annals of the Academy of Medicine, Singapore, 20, 803-804.

31. Ray, U., Dutta, S., Mondal, S., \& Bandyopadhyay, S. (2017). Severe dengue due to secondary hemophagocytic lymphohistiocytosis: A case study. IDCases, 8, 50-53.

32. Ribeiro, E., Kassab, S., Pistone, T., Receveur, M. C., Fialon, P., \& Malvy, D. (2014). Primary dengue fever associated with hemophagocytic syndrome: A report of three imported cases, Bordeaux France. Internal Medicine, 53, 899-902.

33. Sharp, T. M., Gaul, L., Muehlenbachs, A., Hunsperger, E., Bhatnagar, J., Lueptow, R., et al. (2014). Fatal hemophagocytic lymphohistiocytosis associated with locally acquired dengue virus infection - New Mexico and Texas, 2012. MMWR. Morbidity and Mortality Weekly Report, 63, 49-54.

34. Soler Rosario, Y., Garcia, R., \& Fernandez Sein, A. (2010). Dengue virus associated hemophagocytic syndrome in children: A case report. Boletín de la Asociación Médica de Puerto Rico, 102, 49-54.

35. Srichaikul, T., Punyagupta, S., Kanchanapoom, T., Chanokovat, C., Likittanasombat, K., \& Leelasiri, A. (2008). Hemophagocytic syndrome in dengue hemorrhagic fever with severe 
multiorgan complications. Journal of the Medical Association of Thailand $=$ Chotmaihet Thangphaet, 91, 104-109.

36. Tan, L. H., Lum, L. C., Omar, S. F., \& Kan, F. K. (2012). Hemophagocytosis in dengue: Comprehensive report of six cases. Journal of Clinical Virology, 55, 79-82.

37. Wan Jamaludin, W. F., Periyasamy, P., Wan Mat, W. R., \& Abdul Wahid, S. F. (2015). Dengue infection associated hemophagocytic syndrome: Therapeutic interventions and outcome. Journal of Clinical Virology, 69, 91-95.

38. Yoshifuji, K., Oshina, T., Sonokawa, S., Noguchi, Y., Suzuki, S., Tanaka, K., et al. (2016). Domestic dengue infection with hemophagocytic lymphohistiocytosis successfully treated by early steroid therapy. Rinsho ketsueki, 57, 864-868.

39. Hein, N., Bergara, G. H., Moura, N. B., Cardoso, D. M., Hirose, M., Ferronato, A. E., et al. (2015). Dengue fever as a cause of hemophagocytic lymphohistiocytosis. Autopsy \& Case Reports, 5, 33-36.

40. Betancur, J. F., Navarro, E. P., Echeverry, A., Moncada, P. A., Canas, C. A., \& Tobon, G. J. (2015). Hyperferritinemic syndrome: Still's disease and catastrophic antiphospholipid syndrome triggered by fulminant Chikungunya infection: A case report of two patients. Clinical Rheumatology, 34, 1989-1992.

41. Bicakci, Z., Tavil, B., Tezer, H., \& Olcay, L. (2013). Hemophagocytosis in a case with Crimean-Congo hemorrhagic fever and an overview of possible pathogenesis with current evidence. The Turkish Journal of Pediatrics, 55, 344-348.

42. Erduran, E., \& Cakir, M. (2010). Reactive hemophagocytic lymphohistiocytosis and Crimean-Congo hemorrhagic fever. In International journal of infectious diseases. IJID : official publication of the International Society for Infectious Diseases, Canada. e349; author reply e350.

43. Tasdelen Fisgin, N., Fisgin, T., Tanyel, E., Doganci, L., Tulek, N., Guler, N., et al. (2008). Crimean-Congo hemorrhagic fever: Five patients with hemophagocytic syndrome. American Journal of Hematology, 83, 73-76.

44. Lee, J. J., Chung, I. J., Shin, D. H., Cho, S. H., Cho, D., Ryang, D. W., et al. (2002). Hemorrhagic fever with renal syndrome presenting with hemophagocytic lymphohistiocytosis. Emerging Infectious Diseases, 8, 209-210.

45. Lee, J., Jeong, G., Lim, J. H., Kim, H., Park, S. W., Lee, W. J., et al. (2016). Severe fever with thrombocytopenia syndrome presenting with hemophagocytic lymphohistiocytosis. Infect Chemother, 48(4), 338-341.

46. Lin, L., Xu, Y. Z., Wu, X. M., Ge, H. F., Feng, J. X., Chen, M. F., et al. (2016). A rare fatal case of a novel bunyavirus-associated hemophagocytic lymphohistiocytosis. Journal of Infection in Developing Countries, 10, 533-536.

47. Nakano, A., Ogawa, H., Nakanishi, Y., Fujita, H., Mahara, F., Shiogama, K., et al. (2017). Hemophagocytic lymphohistiocytosis in a fatal case of severe fever with thrombocytopenia syndrome. Internal Medicine, 56, 1597-1602.

48. Wiwanitkit, V. (2010). Dengue fever: Diagnosis and treatment. Expert Review of AntiInfective Therapy, 8, 841-845.

49. Hasan, S., Jamdar, S. F., Alalowi, M., Al Ageel, S. M., \& Beaiji, A. (2016). Dengue virus: A global human threat: Review of literature. Journal of International Society of Preventive and Community Dentistry, 6, 1-6.

50. Kularatne, S. A. (2015). Dengue fever. BMJ, 351, h4661.

51. Rajapakse, S., Ranasinghe, C., \& Rodrigo, C. (2010). Corticosteroid therapy in dengue infection- opinions of junior doctors. Journal of Global Infectious Diseases, 2, 199-200.

52. Tam, D. T., Ngoc, T. V., Tien, N. T., Kieu, N. T., Thuy, T. T., Thanh, L. T., et al. (2012). Effects of short-course oral corticosteroid therapy in early dengue infection in Vietnamese patients: A randomized, placebo-controlled trial. Clinical Infectious Diseases, 55, 1216-1224.

53. Zhang, F., \& Kramer, C. V. (2014). Corticosteroids for dengue infection. Cochrane Database of Systematic Reviews, 7, CD003488. 
54. Rajapakse, S., Rodrigo, C., Maduranga, S., \& Rajapakse, A. C. (2014). Corticosteroids in the treatment of dengue shock syndrome. Infection and Drug Resistance, 7, 137-143.

55. Premaratna, R., Jayasinghe, K. G., Liyanaarachchi, E. W., Weerasinghe, O. M., Pathmeswaran, A., \& de Silva, H. J. (2011). Effect of a single dose of methyl prednisolone as rescue medication for patients who develop hypotensive dengue shock syndrome during the febrile phase: A retrospective observational study. International Journal of Infectious Diseases, 15, e433-e434.

56. Wiwanitkit, V. (2015). Haemophagocytic lymphohistiocytosis and dengue. Acta Clinica Belgica, 70, 72 .

57. Ramachandran, B., Balasubramanian, S., Abhishek, N., Ravikumar, K. G., \& Ramanan, A. V. (2011). Profile of hemophagocytic lymphohistiocytosis in children in a tertiary care hospital in India. Indian Pediatrics, 48, 31-35.

58. van de Weg, C. A., Huits, R. M., Pannuti, C. S., Brouns, R. M., van den Berg, R. W., van den Ham, H. J., et al. (2014). Hyperferritinaemia in dengue virus infected patients is associated with immune activation and coagulation disturbances. PLoS Neglected Tropical Diseases, 8 , e3214.

59. Martina, B. E., Koraka, P., \& Osterhaus, A. D. (2009). Dengue virus pathogenesis: An integrated view. Clinical Microbiology Reviews, 22, 564-581.

60. Dilber, E., Cakir, M., Erduran, E., Koksal, I., Bahat, E., Mutlu, M., et al. (2010). High-dose methylprednisolone in children with Crimean-Congo haemorrhagic fever. Tropical Doctor, 40, 27-30.

61. Erduran, E., Bahadir, A., Palanci, N., \& Gedik, Y. (2013). The treatment of crimean-Congo hemorrhagic fever with high-dose methylprednisolone, intravenous immunoglobulin, and fresh frozen plasma. Journal of Pediatric Hematology/Oncology, 35, e19-e24.

62. McElroy, A. K., Erickson, B. R., Flietstra, T. D., Rollin, P. E., Nichol, S. T., Towner, J. S., et al. (2014). Ebola hemorrhagic fever: Novel biomarker correlates of clinical outcome. The Journal of Infectious Diseases, 210, 558-566.

63. van der Ven, A. J., Netea, M. G., van der Meer, J. W., \& de Mast, Q. (2015). Ebola virus disease has features of hemophagocytic lymphohistiocytosis syndrome. Frontiers in Medicine, 2,4 .

64. Cron, R. Q., Behrens, E. M., Shakoory, B., Ramanan, A. V., \& Chatham, W. W. (2015). Does viral hemorrhagic fever represent reactive Hemophagocytic syndrome? The Journal of Rheumatology, 42, 1078-1080.

65. Samransamruajkit, R., Hiranrat, T., Chieochansin, T., Sritippayawan, S., Deerojanawong, J., Prapphal, N., et al. (2008). Prevalence, clinical presentations and complications among hospitalized children with influenza pneumonia. Japanese Journal of Infectious Diseases, 61, 446-449.

66. Beutel, G., Wiesner, O., Eder, M., Hafer, C., Schneider, A. S., Kielstein, J. T., et al. (2011). Virus-associated hemophagocytic syndrome as a major contributor to death in patients with 2009 influenza A (H1N1) infection. Critical Care (London, England), 15, R80.

67. Centers for Disease Control and Prevention. (2018). Influenza (Flu). https://www.cdc.gov/flu.

68. Centers for Disease Control and Prevention. (2017). Human Parainfluenza Viruses (HPIVs). https://www.cdc.gov/parainfluenza.

69. Centers for Disease Control and Prevention. (2018). Adenoviruses. https://www.cdc.gov/ adenovirus.

70. Echavarría, M. (2008). Adenoviruses in immunocompromised hosts. Clinical Microbiology Reviews, 21, 704-715.

71. Qiu, J., Söderlund-Venermo, M., \& Young, N. S. (2017). Human parvoviruses. Clinical Microbiology Reviews, 30, 43-113.

72. Centers for Disease Control and Prevention. (2018). Viral Hepatitis. https://www.cdc.gov/ hepatitis.

73. Inman, R. D., Hodge, M., Johnston, M. E., Wright, J., \& Heathcote, J. (1986). Arthritis, vasculitis, and cryoglobulinemia associated with relapsing hepatitis a virus infection. Annals of Internal Medicine, 105, 700-703. 
74. Schiff, E. R. (1992). Atypical clinical manifestations of hepatitis a. Vaccine, 10(Suppl 1), S18-S20.

75. Iaria, C., Leonardi, M. S., Buda, A., Toro, M. L., \& Cascio, A. (2012). Measles and secondary hemophagocytic lymphohistiocytosis. Emerging Infectious Diseases, 18, 1529. author reply 1529-1530.

76. Komatsuda, A., Chubachi, A., \& Miura, A. B. (1995). Virus-associated hemophagocytic syndrome due to measles accompanied by acute respiratory failure. Internal Medicine, 34, 203-206.

77. Centers for Disease Control and Prevention. (2018). Measles (Rubeola). https://www.cdc. gov/measles.

78. Hiraiwa, K., Obara, K., \& Sato, A. (2005). Mumps virus-associated hemophagocytic syndrome. Emerging Infectious Diseases, 11, 343.

79. Centers for Disease Control and Prevention. (2018). Mumps. https://www.cdc.gov/mumps.

80. Centers for Disease Control and Prevention. (2017). Rubella (German measles, three day measles). https://www.cdc.gov/rubella.

81. de Crom, S. C., Rossen, J. W., van Furth, A. M., \& Obihara, C. C. (2016). Enterovirus and parechovirus infection in children: A brief overview. European Journal of Pediatrics, 175, 1023-1029.

82. Yuzurihara, S. S., Ao, K., Hara, T., Tanaka, F., Mori, M., Kikuchi, N., et al. (2013). Human parechovirus-3 infection in nine neonates and infants presenting symptoms of hemophagocytic lymphohistiocytosis. Journal of Infection and Chemotherapy, 19, 144-148.

83. Vergnano, S., Kadambari, S., Whalley, K., Menson, E. N., Martinez-Alier, N., Cooper, M., et al. (2015). Characteristics and outcomes of human parechovirus infection in infants (20082012). European Journal of Pediatrics, 174, 919-924.

84. Crawford, S. E., Ramani, S., Tate, J. E., Parashar, U. D., Svensson, L., Hagbom, M., et al. (2017). Rotavirus infection. Nature Reviews. Disease Primers, 3, 17083.

85. Quaresma, J. A., Yoshikawa, G. T., Koyama, R. V., Dias, G. A., Fujihara, S., \& Fuzii, H. T. (2015). HTLV-1, immune response and autoimmunity. Viruses, 8, E5.

86. Potter, M. N., Foot, A. B., \& Oakhill, A. (1991). Influenza A and the virus associated haemophagocytic syndrome: Cluster of three cases in children with acute leukaemia. Journal of Clinical Pathology, 44, 297-299.

87. Ando, M., Miyazaki, E., Hiroshige, S., Ashihara, Y., Okubo, T., Ueo, M., et al. (2006). Virus associated hemophagocytic syndrome accompanied by acute respiratory failure caused by influenza A (H3N2). Internal Medicine, 45, 1183-1186.

88. Watanabe, T., Okazaki, E., \& Shibuya, H. (2003). Influenza A virus-associated encephalopathy with haemophagocytic syndrome. European Journal of Pediatrics, 162, 799-800.

89. Mou, S. S., Nakagawa, T. A., Riemer, E. C., McLean, T. W., Hines, M. H., \& Shetty, A. K. (2006). Hemophagocytic lymphohistiocytosis complicating influenza A infection. Pediatrics, 118 , e216-e219.

90. Zhang, Z., Zhang, J., Huang, K., Li, K. S., Yuen, K. Y., Guan, Y., et al. (2009). Systemic infection of avian influenza A virus H5N1 subtype in humans. Human Pathology, 40, 735-739.

91. To, K. F., Chan, P. K., Chan, K. F., Lee, W. K., Lam, W. Y., Wong, K. F., et al. (2001). Pathology of fatal human infection associated with avian influenza A H5N1 virus. Journal of Medical Virology, 63, 242-246.

92. Harms, P. W., Schmidt, L. A., Smith, L. B., Newton, D. W., Pletneva, M. A., Walters, L. L., et al. (2010). Autopsy findings in eight patients with fatal H1N1 influenza. American Journal of Clinical Pathology, 134, 27-35.

93. Katsumi, A., Nishida, T., Murata, M., Terakura, S., Shimada, K., Saito, S., et al. (2011). Virus-associated hemophagocytic syndrome caused by pandemic swine-origin influenza A (H1N1) in a patient after unrelated bone marrow transplantation. Journal of Clinical and Experimental Hematopathology, 51, 63-65. 
94. Ozdemir, H., Ciftci, E., Ince, E. U., Ertem, M., Ince, E., \& Dogru, U. (2011). Hemophagocytic lymphohistiocytosis associated with 2009 pandemic influenza A (H1N1) virus infection. Journal of Pediatric Hematology/Oncology, 33, 135-137.

95. Willekens, C., Cornelius, A., Guerry, M. J., Wacrenier, A., \& Fourrier, F. (2011). Fulminant hemophagocytic lymphohistiocytosis induced by pandemic A (H1N1) influenza: A case report. Journal of Medical Case Reports, 5, 280.

96. Zhang, X. Y., Ye, X. W., Feng, D. X., Han, J., Li, D., \& Zhang, C. (2011). Hemophagocytic lymphohistiocytosis induced by severe pandemic influenza A (H1N1) 2009 virus infection: A case report. Case Reports in Medicine, 2011, 951910.

97. Lai, S., Merritt, B. Y., Chen, L., Zhou, X., \& Green, L. K. (2012). Hemophagocytic lymphohistiocytosis associated with influenza A (H1N1) infection in a patient with chronic lymphocytic leukemia: An autopsy case report and review of the literature. Annals of Diagnostic Pathology, 16, 477-484.

98. Yontem, Y., Ilker, D., Yesim, O., Aysen, T., Gulcihan, O., Ozgur, C., et al. (2013). Analysis of fatal cases of pandemic influenza A (H1N1) virus infections in pediatric patients with leukemia. Pediatric Hematology and Oncology, 30, 437-444.

99. Casciaro, R., Cresta, F., Favilli, F., Naselli, A., De Alessandri, A., \& Minicucci, L. (2014). Macrophage activation syndrome induced by a/H1N1 influenza in cystic fibrosis. Pediatric Pulmonology, 49, E10-E12.

100. Shrestha, B., Omran, A., Rong, P., \& Wang, W. (2015). Report of a fatal pediatric case of hemophagocytic lymphohistiocytosis associated with pandemic influenza A (H1N1) infection in 2009. Pediatrics and Neonatology, 56, 189-192.

101. Schulert, G. S., Zhang, M., Fall, N., Husami, A., Kissell, D., Hanosh, A., et al. (2016). Wholeexome sequencing reveals mutations in genes linked to hemophagocytic lymphohistiocytosis and macrophage activation syndrome in fatal cases of H1N1 influenza. The Journal of Infectious Diseases, 213, 1180-1188.

102. de Jong, M. D., Bach, V. C., Phan, T. Q., Vo, M. H., Tran, T. T., Nguyen, B. H., et al. (2005). Fatal avian influenza A (H5N1) in a child presenting with diarrhea followed by coma. The New England Journal of Medicine, 352, 686-691.

103. Ikebe, T., Takata, H., Sasaki, H., Miyazaki, Y., Ohtsuka, E., Saburi, Y., et al. (2017). Hemophagocytic lymphohistiocytosis following influenza vaccination in a patient with aplastic anemia undergoing allogeneic bone marrow stem cell transplantation. International Journal of Hematology, 105, 389-391.

104. Chokephaibulkit, K., Uiprasertkul, M., Puthavathana, P., Chearskul, P., Auewarakul, P., Dowell, S. F., et al. (2005). A child with avian influenza A (H5N1) infection. The Pediatric Infectious Disease Journal, 24, 162-166.

105. Chan, P. K. (2002). Outbreak of avian influenza A (H5N1) virus infection in Hong Kong in 1997. Clinical Infectious Diseases, 34(Suppl 2), S58-S64.

106. Ng, W. F., To, K. F., Lam, W. W., Ng, T. K., \& Lee, K. C. (2006). The comparative pathology of severe acute respiratory syndrome and avian influenza A subtype H5N1--a review. Human Pathology, 37, 381-390.

107. Hsieh, S. M., \& Chang, S. C. (2006). Insufficient perforin expression in CD8+ T cells in response to hemagglutinin from avian influenza (H5N1) virus. Journal of Immunology, 176, 4530-4533.

108. Peiris, J. S., Yu, W. C., Leung, C. W., Cheung, C. Y., Ng, W. F., Nicholls, J. M., et al. (2004). Re-emergence of fatal human influenza A subtype H5N1 disease. Lancet, 363, 617-619.

109. Henter, J. I., Chow, C. B., Leung, C. W., \& Lau, Y. L. (2006). Cytotoxic therapy for severe avian influenza A (H5N1) infection. Lancet, 367, 870-873.

110. Henter, J. I., Samuelsson-Horne, A., Aricò, M., Egeler, R. M., Elinder, G., Filipovich, A. H., et al. (2002). Treatment of hemophagocytic lymphohistiocytosis with HLH-94 immunochemotherapy and bone marrow transplantation. Blood, 100, 2367-2373. 
111. Horai, Y., Miyamura, T., Takahama, S., Sonomoto, K., Nakamura, M., Ando, H., et al. (2010). Influenza virus B-associated hemophagocytic syndrome and recurrent pericarditis in a patient with systemic lupus erythematosus. Modern Rheumatology, 20, 178-182.

112. Beffermann, N., Pilcante, J., \& Sarmiento, M. (2015). Acquired hemophagocytic syndrome related to parainfluenza virus infection: Case report. Journal of Medical Case Reports, 9, 78.

113. Levy, J., Wodell, R. A., August, C. S., \& Bayever, E. (1990). Adenovirus-related hemophagocytic syndrome after bone marrow transplantation. Bone Marrow Transplantation, 6, 349-352.

114. Seidel, M. G., Kastner, U., Minkov, M., \& Gadner, H. (2003). IVIG treatment of adenovirus infection-associated macrophage activation syndrome in a two-year-old boy: Case report and review of the literature. Pediatric Hematology and Oncology, 20, 445-451.

115. Morimoto, A., Teramura, T., Asazuma, Y., Mukoyama, A., \& Imashuku, S. (2003). Hemophagocytic syndrome associated with severe adenoviral pneumonia: Usefulness of real-time polymerase chain reaction for diagnosis. International Journal of Hematology, 77, 295-298.

116. Imashuku, S., Ueda, I., Teramura, T., Mori, K., Morimoto, A., Sako, M., et al. (2005). Occurrence of haemophagocytic lymphohistiocytosis at less than 1 year of age: Analysis of 96 patients. European Journal of Pediatrics, 164, 315-319.

117. Klein, A., Corazza, F., Demulder, A., Van Beers, D., \& Ferster, A. (1999). Recurrent viral associated hemophagocytic syndrome in a child with Langerhans cell histiocytosis. Journal of Pediatric Hematology/Oncology, 21, 554-556.

118. Iyama, S., Matsunaga, T., Fujimi, A., Murase, K., Kuribayasi, K., Sato, T., et al. (2005). Successful treatment with oral ribavirin of adenovirus-associated hemophagocytic syndrome in a stem cell transplantation recipient. Rinshō Ketsueki, 46, 363-367.

119. Lin, C. I., Yu, H. H., Lee, J. H., Wang, L. C., Lin, Y. T., Yang, Y. H., et al. (2012). Clinical analysis of macrophage activation syndrome in pediatric patients with autoimmune diseases. Clinical Rheumatology, 31, 1223-1230.

120. Hosnut, F. O., Ozcay, F., Malbora, B., Hizli, S., \& Ozbek, N. (2014). Severe adenovirus infection associated with hemophagocytic lymphohistiocytosis. Turkish Journal of Haematology, 31, 103-105.

121. Mellon, G., Henry, B., Aoun, O., Boutolleau, D., Laparra, A., Mayaux, J., et al. (2016). Adenovirus related lymphohistiocytic hemophagocytosis: Case report and literature review. Journal of Clinical Virology, 78, 53-56.

122. Reardon, D. A., Roskos, R., Hanson, C. A., \& Castle, V. (1991). Virus-associated hemophagocytic syndrome following bone marrow transplantation. The American Journal of Pediatric Hematology/Oncology, 13, 305-309.

123. Risdall, R. J., McKenna, R. W., Nesbit, M. E., Krivit, W., Balfour, H. H., Simmons, R. L., et al. (1979). Virus-associated hemophagocytic syndrome: A benign histiocytic proliferation distinct from malignant histiocytosis. Cancer, 44, 993-1002.

124. Schultz, K. A., Neglia, J. P., Smith, A. R., Ochs, H. D., Torgerson, T. R., \& Kumar, A. (2008). Familial hemophagocytic lymphohistiocytosis in two brothers with X-linked agammaglobulinemia. Pediatric Blood \& Cancer, 51, 293-295.

125. Kaya, Z., Ozturk, G., Gursel, T., \& Bozdayi, G. (2005). Spontaneous resolution of hemophagocytic syndrome and disseminated intravascular coagulation associated with parvovirus b19 infection in a previously healthy child. Japanese Journal of Infectious Diseases, 58, 149-151.

126. Larroche, C., Scieux, C., Honderlick, P., Piette, A. M., Morinet, F., \& Bletry, O. (2002). Spontaneous resolution of hemophagocytic syndrome associated with acute parvovirus B19 infection and concomitant Epstein-Barr virus reactivation in an otherwise healthy adult. European Journal of Clinical Microbiology \& Infectious Diseases, 21, 739-742.

127. Dutta, U., Mittal, S., Ratho, R. K., \& Das, A. (2005). Acute liver failure and severe hemophagocytosis secondary to parvovirus B19 infection. Indian Journal of Gastroenterology, 24, $118-119$. 
128. Yilmaz, S., Oren, H., Demircioglu, F., Firinci, F., Korkmaz, A., \& Irken, G. (2006). Parvovirus B19: A cause for aplastic crisis and hemophagocytic lymphohistiocytosis. Pediatric Blood \& Cancer, 47, 861.

129. Hermann, J., Steinbach, D., Lengemann, J., \& Zintl, F. (2003). Parvovirus B 19 associated hemophagocytic syndrome in a patient with hereditary sperocytosis. Klinische Pädiatrie, $215,270-274$.

130. Syruckova, Z., Stary, J., Sedlacek, P., Smisek, P., Vavrinec, J., Komrska, V., et al. (1996). Infection-associated hemophagocytic syndrome complicated by infectious lymphoproliferation: A case report. Pediatric Hematology and Oncology, 13, 143-150.

131. Yuan, C., Asad-Ur-Rahman, F., \& Abusaada, K. (2016). A rare case of Hemophagocytic Lymphohistiocytosis associated with parvovirus B19 infection. Cureus, 8, e897.

132. Yufu, Y., Matsumoto, M., Miyamura, T., Nishimura, J., Nawata, H., \& Ohshima, K. (1997). Parvovirus B19-associated haemophagocytic syndrome with lymphadenopathy resembling histiocytic necrotizing lymphadenitis (Kikuchi's disease). British Journal of Haematology, 96, 868-871.

133. Shirono, K., \& Tsuda, H. (1995). Parvovirus B19-associated haemophagocytic syndrome in healthy adults. British Journal of Haematology, 89, 923-926.

134. Ardalan, M. R., Shoja, M. M., Tubbs, R. S., Esmaili, H., \& Keyvani, H. (2008). Postrenal transplant hemophagocytic lymphohistiocytosis and thrombotic microangiopathy associated with parvovirus b19 infection. American Journal of Transplantation : Official Journal of the American Society of Transplantation and the American Society of Transplant Surgeons, 8, $1340-1344$.

135. Tavera, M., Petroni, J., Leon, L., Minue, E., \& Casadei, D. (2012). Reactive haemophagocytic syndrome associated with parvovirus B19 in a kidney-pancreas transplant patient. Nefrología, $32,125-126$.

136. Matsubara, K., Uchida, Y., Wada, T., Iwata, A., Yura, K., Kamimura, K., et al. (2011). Parvovirus B19-associated hemophagocytic lymphohistiocytosis in a child with precursor B-cell acute lymphoblastic leukemia under maintenance chemotherapy. Journal of Pediatric Hematology/Oncology, 33, 565-569.

137. Sekiguchi, Y., Shimada, A., Imai, H., Wakabayashi, M., Sugimoto, K., Nakamura, N., et al. (2014). A case of recurrent autoimmune hemolytic anemia during remission associated with acute pure red cell aplasia and hemophagocytic syndrome due to human parvovirus B19 infection successfully treated by steroid pulse therapy with a review of the literature. International Journal of Clinical and Experimental Pathology, 7, 2624-2635.

138. Uike, N., Miyamura, T., Obama, K., Takahira, H., Sato, H., \& Kozuru, M. (1993). Parvovirus B19-associated haemophagocytosis in Evans syndrome: Aplastic crisis accompanied by severe thrombocytopenia. British Journal of Haematology, 84, 530-532.

139. Mayama, M., Yoshihara, M., Kokabu, T., \& Oguchi, H. (2014). Hemophagocytic lymphohistiocytosis associated with a parvovirus B19 infection during pregnancy. Obstetrics and Gynecology, 124, 438-441.

140. Kishore, J., \& Kishore, D. (2014). Fatal missed case of hemophagocytic lymphohistiocytosis co-infected with parvovirus B19 and Epstein-Barr virus in an infant: Test hyperferritinaemia early. Indian Journal of Medical Microbiology, 32, 181-183.

141. Sood, N., \& Yadav, P. (2012). Hemophagocytic syndrome associated with concomitant Klebsiella and parvovirus B-19 infection. Indian Journal of Pathology \& Microbiology, 55, 124-125.

142. Rouphael, N. G., Talati, N. J., Vaughan, C., Cunningham, K., Moreira, R., \& Gould, C. (2007). Infections associated with haemophagocytic syndrome. The Lancet Infectious Diseases, 7, 814-822.

143. Ramachandra, G., Shields, L., Brown, K., \& Ramnarayan, P. (2010). The challenges of prompt identification and resuscitation in children with acute fulminant myocarditis: Case series and review of the literature. Journal of Paediatrics and Child Health, 46, 579-582. 
144. Tsuda, H., Maeda, Y., Nakagawa, K., Nakayama, M., Nishimura, H., Ishihara, A., et al. (1994). Parvovirus B19-associated haemophagocytic syndrome with prominent neutrophilia. British Journal of Haematology, 86, 413-414.

145. Butin, M., Mekki, Y., Phan, A., Billaud, G., Di Filippo, S., Javouhey, E., et al. (2013). Successful immunotherapy in life-threatening parvovirus B19 infection in a child. The Pediatric Infectious Disease Journal, 32, 789-792.

146. Watanabe, M., Shibuya, A., Okuno, J., Maeda, T., Tamama, S., \& Saigenji, K. (2002). Hepatitis a virus infection associated with hemophagocytic syndrome: Report of two cases. Internal Medicine, 41, 1188-1192.

147. Tuon, F. F., Gomes, V. S., Amato, V. S., Graf, M. E., Fonseca, G. H., Lazari, C., et al. (2008). Hemophagocytic syndrome associated with hepatitis a: Case report and literature review. Revista do Instituto de Medicina Tropical de São Paulo, 50, 123-127.

148. Russo, R. A., Rosenzweig, S. D., \& Katsicas, M. M. (2008). Hepatitis A-associated macrophage activation syndrome in children with systemic juvenile idiopathic arthritis: Report of 2 cases. The Journal of Rheumatology, 35, 166-168.

149. Bay, A., Bosnak, V., Leblebisatan, G., Yavuz, S., Yilmaz, F., \& Hizli, S. (2012). Hemophagocytic lymphohistiocytosis in 2 pediatric patients secondary to hepatitis a virus infection. Pediatric Hematology and Oncology, 29, 211-214.

150. Canoz, P. Y., Afat, E., Temiz, F., Azizoglu, N. O., Citilcioglu, H. B., Tumgor, G., et al. (2014). Reactive hemophagocytic lymphohistiocytosis after hepatitis a infection. Indian Journal of Hematology \& Blood Transfusion, 30, 46-48.

151. Cho, E., Cha, I., Yoon, K., Yang, H. N., Kim, H. W., Kim, M. G., et al. (2010). Hemophagocytic syndrome in a patient with acute tubulointerstitial nephritis secondary to hepatitis a virus infection. Journal of Korean Medical Science, 25, 1529-1531.

152. Ishii, H., Yamagishi, Y., Okamoto, S., Saito, H., Kikuchi, H., \& Kodama, T. (2003). Hemophagocytic syndrome associated with fulminant hepatitis a: A case report. The Keio Journal of Medicine, 52, 38-51.

153. Kyoda, K., Nakamura, S., Machi, T., Kitagawa, S., Ohtake, S., \& Matsuda, T. (1998). Acute hepatitis a virus infection-associated hemophagocytic syndrome. The American Journal of Gastroenterology, 93, 1187-1188.

154. Navamani, K., Natarajan, M. M., Lionel, A. P., \& Kumar, S. (2014). Hepatitis a virus infection-associated hemophagocytic lymphohistiocytosis in two children. Indian Journal of Hematology \& Blood Transfusion, 30, 239-242.

155. Onaga, M., Hayashi, K., Nishimagi, T., Nagata, K., Uto, H., Kubuki, Y., et al. (2000). A case of acute hepatitis a with marked hemophagocytosis in bone marrow. Hepatology Research : The Official Journal of the Japan Society of Hepatology, 17, 205-211.

156. Tai, C. M., Liu, C. J., \& Yao, M. (2005). Successful treatment of acute hepatitis A-associated hemophagocytic syndrome by intravenous immunoglobulin. Journal of the Formosan Medical Association, 104, 507-510.

157. McPeake, J. R., Hirst, W. J., Brind, A. M., \& Williams, R. (1993). Hepatitis a causing a second episode of virus-associated haemophagocytic lymphohistiocytosis in a patient with Still's disease. Journal of Medical Virology, 39, 173-175.

158. Aleem, A., Al Amoudi, S., Al-Mashhadani, S., \& Siddiqui, N. (2005). Haemophagocytic syndrome associated with hepatitis-B virus infection responding to etoposide. Clinical and Laboratory Haematology, 27, 395-398.

159. Yu, M. G., \& Chua, J. (2016). Virus-associated haemophagocytic lymphohistiocytosis in a youn-g Filipino man. BMJ Case Reports, 2016, bcr2016214655.

160. Faurschou, M., Nielsen, O. J., Hansen, P. B., Juhl, B. R., \& Hasselbalch, H. (1999). Fatal virus-associated hemophagocytic syndrome associated with coexistent chronic active hepatitis B and acute hepatitis C virus infection. American Journal of Hematology, 61, 135-138.

161. Tierney, L. M., Thabet, A., \& Nishino, H. (2011). Case records of the Massachusetts General Hospital. Case 10-2011. A woman with fever, confusion, liver failure, anemia, and thrombocytopenia. The New England Journal of Medicine, 364, 1259-1270. 
162. Guerra, J. A. A. A., Kampa, K. C., Morsoletto, D. G. B., Junior, A. P., \& Ivantes, C. A. P. (2017). Hepatitis E: A literature review. Journal of Clinical and Translational Hepatology, 5, 376-383.

163. Kamihira, T., Yano, K., Tamada, Y., Matsumoto, T., Miyazato, M., Nagaoka, S., et al. (2008). Case of domestically infected hepatitis E with marked thrombocytopenia. Nihon Shokakibyo Gakkai Zasshi, 105, 841-846.

164. Leroy, M., Coiffier, G., Pronier, C., Triquet, L., Perdriger, A., \& Guggenbuhl, P. (2015). Macrophage activation syndrome with acute hepatitis E during tocilizumab treatment for rheumatoid arthritis. Joint, Bone, Spine, 82, 278-279.

165. Choudhary, S. K., Agarwal, A., Mandal, R. N., \& Grover, R. (2016). Hemophagocytic lymphohistiocytosis associated with hepatitis a and hepatitis E co-infection. Indian Journal of Pediatrics, 83, 607-608.

166. Tsunemi, Y., Matsushita, T., Nagayama, T., Takahashi, T., \& Tamaki, T. (2001). A case of virus-associated hemophagocytic syndrome due to measles. The Japanese Journal of Dermatology, 111, 1591-1596.

167. Otagiri, T., Mitsui, T., Kawakami, T., Katsuura, M., Maeda, K., Ikegami, T., et al. (2002). Haemophagocytic lymphohistiocytosis following measles vaccination. European Journal of Pediatrics, 161, 494-496.

168. Buda, P., Gietka, P., Wieteska-Klimczak, A., Smorczewska-Kiljan, A., \& Książyk, J. (2016). Autoimmune/inflammatory syndrome leading to macrophage activation syndrome: An example of autoinflammatory spectrum disorder? The Israel Medical Association Journal, 18, 571.

169. Xing, Q., \& Xing, P. (2013). Mumps caused hemophagocytic syndrome: A rare case report. The American Journal of Emergency Medicine, 31, 1000.e1001-1000.e1002.

170. Takenaka, H., Kishimoto, S., Ichikawa, R., Shibagaki, R., Kubota, Y., Yamagata, N., et al. (1998). Virus-associated haemophagocytic syndrome caused by rubella in an adult. The British Journal of Dermatology, 139, 877-880.

171. Takeoka, Y., Hino, M., Oiso, N., Nishi, S., Koh, K. R., Yamane, T., et al. (2001). Virusassociated hemophagocytic syndrome due to rubella virus and varicella-zoster virus dual infection in patient with adult idiopathic thrombocytopenic purpura. Annals of Hematology, 80, 361-364.

172. Baykan, A., Akcakus, M., \& Deniz, K. (2005). Rubella-associated hemophagocytic syndrome in an infant. Journal of Pediatric Hematology/Oncology, 27, 430-431.

173. Koubaa, M., Marrakchi, C., Maaloul, I., Makni, S., Berrajah, L., Elloumi, M., et al. (2012). Rubella associated with hemophagocytic syndrome. First report in a male and review of the literature. Mediterranean Journal of Hematology and Infectious Diseases, 4, e2012050.

174. Guerin, C., Pozzetto, B., \& Berthoux, F. (1989). Hemophagocytic syndrome associated with coxsackie virus a 9 infection in a non-immunosuppressed adult. Intensive Care Medicine, 15, 547-548.

175. Barre, V., Marret, S., Mendel, I., Lesesve, J. F., \& Fessard, C. I. (1998). Enterovirus-associated haemophagocytic syndrome in a neonate. Acta Paediatrica, 87, 469-471.

176. Kashiwagi, Y., Kawashima, H., Sato, S., Ioi, H., Amaha, M., Takekuma, K., et al. (2007). Virological and immunological characteristics of fatal virus-associated haemophagocytic syndrome (VAHS). Microbiology and Immunology, 51, 53-62.

177. Letsas, K. P., Filippatos, G. S., Delimpasi, S., Spanakis, N., Kounas, S. P., Efremidis, M., et al. (2007). Enterovirus-induced fulminant myocarditis and hemophagocytic syndrome. The Journal of Infection, 54, e75-e77.

178. Katsibardi, K., Moschovi, M. A., Theodoridou, M., Spanakis, N., Kalabalikis, P., Tsakris, A., et al. (2008). Enterovirus-associated hemophagocytic syndrome in children with malignancy: Report of three cases and review of the literature. European Journal of Pediatrics, 167, 97-102.

179. Lindamood, K. E., Fleck, P., Narla, A., Vergilio, J. A., Degar, B. A., Baldwin, M., et al. (2011). Neonatal enteroviral sepsis/meningoencephalitis and hemophagocytic lymphohistiocytosis: Diagnostic challenges. American Journal of Perinatology, 28, 337-346. 
180. Fukazawa, M., Hoshina, T., Nanishi, E., Nishio, H., Doi, T., Ohga, S., et al. (2013). Neonatal hemophagocytic lymphohistiocytosis associated with a vertical transmission of coxsackievirus B1. Journal of Infection and Chemotherapy, 19, 1210-1213.

181. Hara, S., Kawada, J., Kawano, Y., Yamashita, T., Minagawa, H., Okumura, N., et al. (2014). Hyperferritinemia in neonatal and infantile human parechovirus-3 infection in comparison with other infectious diseases. Journal of Infection and Chemotherapy, 20, 15-19.

182. Nanmoku, K., Yamamoto, T., Tsujita, M., Hiramitsu, T., Goto, N., Katayama, A., et al. (2015). Virus-associated hemophagocytic syndrome in renal transplant recipients: Report of 2 cases from a single center. Case Reports in Hematology, 2015, 876301.

183. Park, M., Yun, Y. J., Woo, S. I., Lee, J. W., Chung, N. G., \& Cho, B. (2015). Rotavirusassociated hemophagocytic lymphohistiocytosis (HLH) after hematopoietic stem cell transplantation for familial HLH. Pediatrics International, 57, e77-e80.

184. Takahashi, S., Oki, J., Miyamoto, A., Koyano, S., Ito, K., Azuma, H., et al. (1999). Encephalopathy associated with haemophagocytic lymphohistiocytosis following rotavirus infection. European Journal of Pediatrics, 158, 133-137.

185. Nagao, T., Takahashi, N., Saitoh, H., Noguchi, S., Guo, Y. M., Ito, M., et al. (2012). Adult T-cell leukemia-lymphoma developed from an HTLV-1 carrier during treatment of B-cell lymphoma-associated hemophagocytic syndrome. Rinshō Ketsueki, 53, 2008-2012. 